\title{
The Glass Ceiling: Existence Barriers Affecting Women's Career Development
}

Submitted 23/05/20, $1^{\text {st }}$ revision 12/06/20, $2^{\text {nd }}$ revision 30/08/20, accepted 30/09/20

\author{
Merita Begolli Dauti ${ }^{1}$, Rron Dauti ${ }^{2}$
}

\begin{abstract}
:
Purpose: The primary aim of the study was to investigate and analyze the barriers to women's career development.

Design/Methodology/Approach: The overall study is a structure based on the conceptual framework created using the relevant literature review, analyzing and researching more about the women career development influenced by Internal Business Structural Barriers, Societal Barriers, Governmental Barriers, Situational Barriers, Personal Barriers, of "Glass ceiling" $(G C)$ in the private sector, in the hospitality industry. The data were collected from 150 women employed in the hospitality industry, while 132 out of 150 responded to the questionnaire.

Findings: From the analysis of the general findings of the study, it can be concluded that referring to the purpose of the study, the influence of "Glass ceiling" barriers on the WCD were achieved, and the influence of GC barriers on WCD was also identified, which enables the women career development in the private sector of the hospitality industry in Kosovo.

Practical implications: Although women already make up a significant contribution to the business world and the hotel industry workforce, men continue to take up most managerial positions. Despite their academic advancement and interest in managing this sector, they are still influenced by "Glass Ceiling" as a barrier for women to advance in their careers at senior levels of supervisory and managerial positions.

Originality/value: Due to the lack of research on the "Glass Ceiling" such a problem has not been researched in Kosovo. This study contributes to the literature on the challenges and barriers faced by women in developing in their careers.
\end{abstract}

Keywords: Education, poverty; panel data analysis.

JEL codes: I2, I3, O14.

Paper Type: Research article.

ISSN: 2241-4754, H index 10, Q3.

\footnotetext{
${ }^{1}$ Assistant, Faculty of management in tourism, hospitality and environment, University

'Haxhi Zeka”, Peja, Kosovo, E-mail: merita.begolli@unhz.eu;

${ }^{2}$ Postgraduate Student, Faculty of Businesses University 'Haxhi Zeka”, Peja, Kosovo, E-mail: rron_dauti@hotmail.com;
} 


\section{Introduction}

In recent years, tourism has become one of the economic sectors with very rapid development and has had continuous growth; at the same time, it is considered a main source of generating new jobs (UNWTO, 2015). Tourism affects citizens' economy and lives by trying to be a savior for many destinations in Kosovo. Although Kosovo is a small country, it has a favorable geographic position and owns important underground resources, relief, human resources, and has a suitable climate for flora and fauna. Kosovo is located in Eastern Europe, it is characterized by its central position in the Balkan Peninsula. It is bordered by the following states: Albania, North Macedonia, Serbia, and Montenegro (UNDP, 2002). The area of Kosovo is 10,908 $\mathrm{km}^{2}$ of where live around 1,796,376 inhabitants. Kosovo is surrounded by high mountains, with some mountain peaks exceeding 2,000 $\mathrm{m}$ above sea level, and the highest peak is Gjeravica 2,656m (Çavolli, 1997).

Hotel capacities in Kosovo, according to the type of accommodation, in total are 466. The classification of the labour market for the population of Kosovo is, total population (for 2019) 1,796,376 (Men: 903,430; Women: 892,946). Employment by profession and gender (in \%), legislators, officials, and senior managers (Men $9.5 \%$ Women 6.2\%). Employment by activities and gender (in \%), accommodation activities, and food services (Men 7.0\% Women 4.6\%) (KAS, 2019). So, as it is documented above, based on the Kosovo Agency of Statistics data, there is a clear lack of empowerment of women in leadership positions, and this continues to be a widespread challenge in the labor market in the hospitality industry in Kosovo. Globally, women are inadequately represented in decision-making positions and other positions of power, responsibility, and leadership, despite the increase in the level of formal employment in recent decades.

\section{Purpose and Objectives of the Study}

The study's primary aim was to investigate and analyze the barriers to women's career development influenced by the Internal Business Structural Barriers, Societal Barriers, Governmental Barriers, Situational Barriers, and Personal Barriers of "Glass Ceiling" in the private sector of the hospitality industry. The purpose of the study was expressed through the following objectives:

- To review the literature as a basis for raising hypotheses and identifying the research model;

- To identify the existence of the "Glass Ceiling" in the private sector in the hospitality industry in the Republic of Kosovo;

- To identify barriers which generate the "Glass Ceiling";

- To analyze and synthesize these barriers that contribute to "Glass Ceiling" to make a model that provides a new solution to any obstacle or challenge faced by women in this sector; 
- The findings of this study and the exploration of barriers that generate the creation of the "Glass Ceiling" can be beneficial for the hospitality industry and the most effective advancement of women's career development.

\section{Research Hypotheses}

This study aimed to facilitate the process of research and data collection needed to test the hypotheses. One of the goals of the study was to research and analyze the progress of the WCD influenced by the Internal Business Structural Barriers, Societal Barriers, Governmental Barriers, Situational Barriers, and Personal Barriers of the "Glass Ceiling" in the private sector of the hospitality industry in the Republic of Kosovo. Therefore, concerning the subject in question, the following hypotheses were raised:

\section{H1: Internal Business Structural Barriers influence women's career development} (WCD).

H2: Societal Barriers influence women's career development (WCD).

H3: Government Barriers influence women's career development (WCD).

H4: Situational Barriers influence women's career development (WCD).

H5: Personal Barriers influence women's career development (WCD).

To verify the raised hypotheses, the Women's career development (WCD) has been considered as the dependent variable, which is based on three components: 1 . CareerFocused refers to the employees interested in advancing and developing in their careers. Highly career-focused, people try to develop their profession. 2. Family support identifies support from family members for the success of family members in their profession. This form of support from family members contributes to advances in the professional career and balance of life-work-family. 3. Attitudes towards the Organisation refers to the opinions of employees regarding the organization. People with positive attitudes about the organization have originated and developed their careers within it, based on the study by Afza and Newaz (2008).

The independent variables (GC) are Internal Business Structural Barriers, Societal Barriers, Government Barriers, Personal Barriers, Situational Barriers (Bazazo et al., 2017), as adapted by Clevenger and Singh (2013), and (Kiaye and Singh, 2013). At the same time, the current research considers five barriers that women face in their career development (WCD): Internal Business Structural Barriers, Societal Barriers, Governmental Barriers, Situational Barriers, and Personal Barriers.

\subsection{Conceptual Framework}

The conceptual framework of the model is presented in Figure 1. 
Figure 1. Conceptual Framework

Independent Variable (GC)

Dependent Variable (WCD)

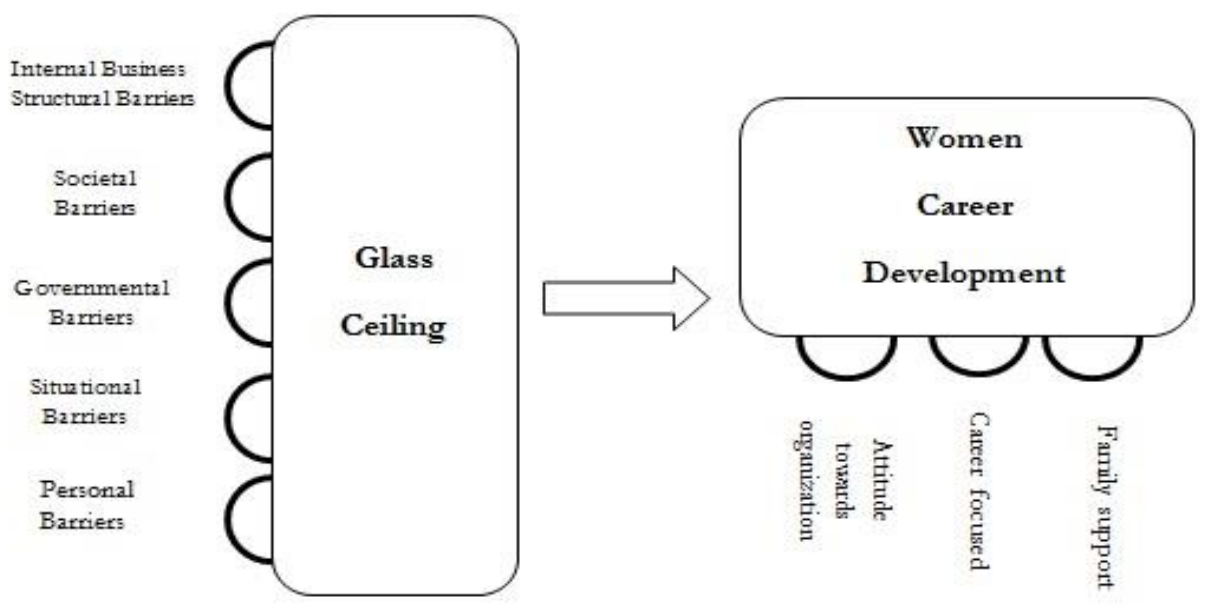

Source: Authors.

\section{Literature Review}

Entrepreneurship is globally recognized as a great benefit to individuals and countries as it is a driver of job growth and creation (Chimona and Mazirir, 2015). Although the percentage of women in leadership positions has increased in recent years, despite this increase is not satisfactory in representing women in leadership positions, which is considered a challenge for society and businesses (Schuh et al., 2014). The term "Glass Ceiling" has been used in scientific discussions since the mid-1980s to explain women's non-representation in managerial positions. The metaphor describes the invisible barrier of prejudice and discrimination, an invisible "Glass Ceiling" that women face as they approach the top of the enterprise (Glass Ceiling Commission, 1995). Therefore, "Glass Ceiling" as a term means that, despite women's qualifications, they still find it impossible to rise to the highest levels in the enterprise (Steven et al., 2013). Although is increasing women's participation in higher education and is almost similar or larger than men, there is still inequality in achieving leadership positions (Myers, 2010).

In the hospitality industry's management, women have characteristics for the work they do and features to achieve high results (Bateson, 1994). In addition to the hospitality industry and the world economy in general, women leaders are capable and valued for management and their leadership in corporations (Paustian et al., 2014). They tend to listen to their co-workers, respect different perspectives, and find solutions to problems. Female managers support their staff in a narrower way than 
male managers ( $\mathrm{Ng}$ and Pine, 2003). Moreover, women demonstrate high performance in organizational work and problem solving, finance, management, and economics knowledge. General female executives include the value of teamwork and collaboration, delegate more, and are more patient than male managers (Marinakou, 2014). If organizations do not exploit the maximum potential of female employees, they lose first, they do not fully utilize the unique talent and perspectives that women carry, and second, they will not get the most out of what they have invested, in money, time for female employees (Elda et al., 2018; Oakley, 2000; Adler, 1993). The complexity of the "Glass Ceiling" phenomenon in organizations requires a methodology that can provide access to its subtitle displays and knowledge and understanding through acquired practices, difficult to challenge, and difficult to observe (Veale and Gold, 1998).

\subsection{The Leadership of Women in the Hospitality Industry}

About half of the total population of the world is female, women performed within the four walls of the house, but now in modern times, they surpassed these walls and began to have access to various economic sectors, among them in the tourism and hospitality sector (Styal, 1990; Palikhe and Amin, 2018). Many academic debates argue that women are successful in leading the hospitality industry. For their management success, they can identify a fault and, at the same time, apologize. They have a strong character, benevolent behavior, and, at the same time, they have patience. Moreover, female leaders try to revolutionize the management style and culture by providing a more appropriate environment. In terms of transformations, women leaders are highly valued, and they can be corporate leaders not only in hotels but in the global economy in general (Eagly et al., 2003; Paustian-Underdahl et al., 2003).

Moreover, women tend to possess features to make changes to the organization, where these features allow them to make drastic changes by providing a vision for the future (Brownell and Walsh, 2008). According to Brownell (2004), women can work and also organize others around a common goal. He further clarified that in a second personality study, he found the following qualities in female managers: they are fair, tireless, have the ability to motivate others, are determined, calm, etc., all of these characteristics contribute towards the success of the organization. Women play an important role in the workplace indeed (Brownell, 2004).

\section{Research Instruments}

In order to provide important and relevant data, accurate research tools are needed. In this study, the questionnaire was used as the main research instrument related to a series of written questions about the phenomenon taken into account. Within the questionnaire, in addition to short questions, there were also Likert scale questions where respondents were asked to rate statements using a scale: from 1- Strongly 
disagree, 2- Disagree, 3 - Slightly Agree, 4 - Agree, 5 - Strongly agree, which have been used to determine the level of importance placed on issues which refer to the women career development influenced by the Barriers of the "Glass Ceiling". The participants of the study were women who currently work in the private sector of the hotel industry. In general, all respondents had a positive attitude and were willing to express their opinion. As mentioned above, a sample of 132 participants were answered, while the total number of distributed questionnaires was 150. The respondents answered the questionnaire without any hesitation.

\subsection{Data Analysis and Discussion of Findings}

From a total of 132 respondents, the analysis of the general profile showed, that 46 of them were aged $18-24$ or $34.85 \%, 28$ or $21.21 \%$ of them are aged $25-34$ years, 31 or $23.49 \%$ are aged $35-44,19$ or $14.39 \%$ are aged $45-54$, and 8 or $6.06 \%$ are aged $55-$ 65 years. According to the respondents, none of the surveyed women hold a doctorate, while 48 or $36.36 \%$ have only high school or vocational school education, 42 or $31.82 \%$ have higher education - university education, and 29 or $21.97 \%$ have finished postgraduate education. The following are the data for work experience: 34 or $25.75 \%$ of respondents have less than 1 year of work experience in this sector while 41 or $31.06 \%$ of respondents have 2-4 years of work experience. 32 or $24.25 \%$ of respondents have 5-7 years of work experience, 14 or $10.60 \%$ of respondents have 810 years of work experience, and 11 or $8.33 \%$ of respondents have over 11 years of work experience in this sector. As far as marital status is concerned, out of the total of 132 women surveyed, 48 women or $36.36 \%$ of the total number are single, 35 or $26.51 \%$ are married with children, 22 or $16.67 \%$ of the total number of respondents are married without children, 12 respondents or $9.09 \%$ are divorced, and 15 surveyed women or $11.37 \%$ are widows.

Table 1 presents the discriptive statistics of the variables.

Table 1. Descriptive statistics

\begin{tabular}{|l|l|l|l|l|l|}
\hline Variables & $\mathbf{N}$ & Minimum & Maximum & Mean & $\begin{array}{l}\text { Standard } \\
\text { Deviation }\end{array}$ \\
\hline Women Career Development & 132 & 1 & 5 & 4.17 & 1.04 \\
\hline $\begin{array}{l}\text { Internal Business Structural } \\
\text { Barriers }\end{array}$ & 132 & 1 & 5 & 4.24 & 1.03 \\
\hline Societal Barriers & 132 & 1 & 5 & 4.05 & 1.08 \\
\hline Governmental Barriers & 132 & 1 & 5 & 3.95 & 1.28 \\
\hline Situational Barriers & 132 & 1 & 5 & 3.31 & 1.30 \\
\hline Personal Barriers & 132 & 1 & 5 & 2.12 & 1.21 \\
\hline
\end{tabular}

Source: Authors.

The reliability analysis was used to measure the internal stability of the data. According to Pallant (2001), a coefficient of scale greater than 0.7 is considered a construct with valid measurements. 
It can be seen, in Table 2, that the Cronbach alpha of the WCD is 0.791 , which indicates a high level of internal stability. The reliability test (Cronbach alpha) for the following variables as shown in Table 2 are as follows:

- Internal Business Structural Barriers is 0.778 .

- Societal Barriers is 0.765 .

- Governmental Barriers is 0.784 .

- $\quad$ Situational Barriers is 0.787 .

- Personal Barriers is 0.791 .

Therefore, it is understood that the data are reliable, and there is consistency between the data.

Table 2. Reliability Test

\begin{tabular}{|l|l|l|}
\hline Variables & $\begin{array}{l}\text { Number } \\
\text { items }\end{array}$ & $\begin{array}{l}\text { Cronbach } \\
\text { alpha }\end{array}$ \\
\hline Women Career Development & 10 & 0.791 \\
\hline Internal Business Structural Barriers & 4 & 0.778 \\
\hline Societal Barriers & 6 & 0.765 \\
\hline Governmental Barriers & 4 & 0.784 \\
\hline Situational Barriers & 7 & 0.787 \\
\hline Personal Barriers & 6 & 0.791 \\
\hline
\end{tabular}

Source: Authors.

A correlation matrix is a table showing correlation coefficients between the variables. The correlations assess the strength of the linear correlation between two variables (Table 3). The correlation coefficients range from -1.0 (a perfect negative correlation) to a positive 1.0 (a perfect positive correlation). The closer the correlation coefficients are to -1.0 or 1.0 , the stronger the correlation. The closer a correlation coefficient is to zero, the weaker the correlation between the two variables (Freedman, Pisani, and Purves, 2007).

Table 3. Correlation matrix

\begin{tabular}{|l|l|l|l|l|l|}
\cline { 2 - 5 } \multicolumn{1}{c|}{} & $\begin{array}{l}\text { Glass } \\
\text { ceiling } \\
\text { barriers }\end{array}$ & $\begin{array}{l}\text { Women } \\
\text { Career } \\
\text { Development }\end{array}$ & $\begin{array}{l}\text { Attitude } \\
\text { towards } \\
\text { organization }\end{array}$ & $\begin{array}{l}\text { Career } \\
\text { focused }\end{array}$ & $\begin{array}{l}\text { Family } \\
\text { support }\end{array}$ \\
\hline $\begin{array}{l}\text { Glass ceiling } \\
\text { barriers }\end{array}$ & 1 & $-.672^{* *}$ & $-.557^{* *}$ & $-.668^{* *}$ & $-.576^{* *}$ \\
\hline
\end{tabular}

Note: ** Correlation is significant at the 0.01 level (2-tailed).

Source: Authors.

The findings showed that the correlation coefficient for Glass Ceiling barriers and attitude towards the organization is -.557 with significance .000 . So, there is a strong negative correlation between Glass Ceiling barriers and attitude towards the organization. There is also strong negative correlation between Glass Ceiling barriers 
and Career-focused with a correlation coefficient -.668 and significance .000. Also, in the following variable, there is a negative correlation between Glass Ceiling barriers and Family support with the correlation coefficient values -.576 and significance .000 . Based on Table 3 above, among the variables, it is seen that there is a strong negative correlation between Glass Ceiling barriers and Women Career Development with the correlation coefficient -.672 and significance .000 .

\subsection{Multiple Regression}

Multiple regression allows the general state of the model (explanations of variables) and each independent variable's relative contribution to the dependent variable to be determined. The multiple regression is an extension of simple linear regression. It is used when we intend to foresee a variable's value based on the value of two or more other variables. Based on the literature and objectives of this study, the regression model is specified as follows:

- Women Career Development $=f$ (Internal Business Structural Barriers, Societal Barriers, Governmental Barriers, Situational Barriers, Personal Barriers)

- Women Career Developmentt $=\beta 0+\beta 1$ Internal Business Structural Barriers $+\beta 2$ Societal Barriers $+\beta 3$ Governmental Barriers $+\beta 5$ Situational Barriers $+\beta 6$ Personal Barriers $+\varepsilon t$

The variable we want to foresee is the dependent variable, while the variables used to predict the value of the dependent variable are called independent variables. So, the model was constructed by taking Women Career Development as the dependent variable. In contrast, as independent variables, the influence of which is expressed on Women Career Development, are taken the Internal Business Structural Barriers, the Societal Barriers, the Governmental Barriers, the Situational Barriers and, the Personal Barriers.

Table 4. St.error, T-test and P-values

\begin{tabular}{|l|l|l|l|l|l|l|}
\hline Variable & (Constant) & $\begin{array}{l}\text { Internal } \\
\text { Business } \\
\text { Structural } \\
\text { Barriers }\end{array}$ & $\begin{array}{l}\text { Societal } \\
\text { Barriers }\end{array}$ & $\begin{array}{l}\text { Governmental } \\
\text { Barriers }\end{array}$ & $\begin{array}{l}\text { Situational } \\
\text { Barriers }\end{array}$ & $\begin{array}{l}\text { Personal } \\
\text { Barriers }\end{array}$ \\
\hline St. Error & .094 & .091 & .130 & .081 & .075 & .043 \\
\hline T- statistics & 61.023 & -4.012 & 4.448 & -1.895 & 1.809 & -23.717 \\
\hline (P-values ) & .000 & .000 & .000 & .060 & .073 & .000 \\
\hline
\end{tabular}

Source: Authors.

Table 4 presents the standard errors, the t-test, and the p-value for each variable. If all the variables included turn out to be statistically significant, then, in general, the model will result as significant. The standard errors (s.e) indicate the average deviation of estimates from the parameters' true value. P - values (Probability values), 
$\mathrm{P}$ values for coefficients indicate whether these correlations are statistically significant; if the P-value is less than 0.05 (or 5\%), then the result will be considered statistically significant. According to the model values for (Internal Business Structural Barriers) t-statistic $=-4.012$ with probability .000 ; for (Societal Barriers) $\mathrm{t}$ statistics $=4,448$ with probability .000 ; for (Governmental Barriers) t- statistics $=$ 1.895 with probability .060 ; for (Situational Barriers) t-statistics $=1.809$ with probability .073; for (Personal Barriers) t-statistics $=-23.717$ with probability .000 .

Table 5 presents the regression results. $\mathrm{R}$ - squared shows how close the observations are to the regression line. The values of this coefficient are $0 \leq \mathrm{R} 2 \leq 1$. If $\mathrm{R} 2=1$, then all observations lie on the regression line, whereas, when R $2=0$, no observations lie on the regression line. In our example, there is a coefficient of determination R2 = .567 , which shows that the independent variables explain $56.7 \%$ of Women's Career Development variation. All variables with a probability of less than $5 \%$ indicate significant variables in this model.

Table 5. Regression Coefficients

\begin{tabular}{|l|l|l|l|l|l|l|}
\hline Variable & (Constant) & $\begin{array}{l}\text { Internal } \\
\text { Business } \\
\text { Structural } \\
\text { Barriers }\end{array}$ & $\begin{array}{l}\text { Societal } \\
\text { Barriers }\end{array}$ & $\begin{array}{l}\text { Governmental } \\
\text { Barriers }\end{array}$ & $\begin{array}{l}\text { Situational } \\
\text { Barriers }\end{array}$ & $\begin{array}{l}\text { Personal } \\
\text { Barriers }\end{array}$ \\
\hline Coefficients & 5.744 & -.365 & .577 & -.153 & .135 & -1.031 \\
\hline P- values & .000 & .000 & .000 & .060 & .073 & .000 \\
\hline F & 27.28 & .000 & \\
\hline R - square & .567 \\
\hline $\begin{array}{l}\text { Adjusted R } \\
\text { Square }\end{array}$ & .542 & & \\
\hline
\end{tabular}

Source: Authors.

As seen from Tables 4 and 5 the independent variables Internal Business Structural Barriers, Societal Barriers, Personal Barriers have p-value less than .05 and are important for the model construction, whereas the variables Governmental Barriers, and Situational Barriers, have value greater than .05 , (.06 and .073 respectively) which means that they are not significant predictors of WCD. According to this result, except for the Governmental Barriers and the Situational Barriers, the other factors are significantly predictive of WCD.

Respectively, the model is expressed in the following form:

Women Career Developmentt $=5.744-.365$ Internal Business Structural Barriers + .577 Societal Barriers - 1.031 Personal Barriers $+\varepsilon t$

Based on the regression results, $\mathrm{H} 1, \mathrm{H} 2$ and $\mathrm{H} 5$ are approved, so the Internal Business Structural Barriers have a negative influence, Societal Barriers have a positive influence, and Personal Barriers have a negative influence on the Women Career 
Development. So through the results obtained, we reach to prove three of five hypotheses raised.

\begin{tabular}{|l|l|l|l|l|l|}
\hline Hypotheses & $\mathrm{H}_{1}$ & $\mathrm{H}_{2}$ & $\mathrm{H}_{3}$ & $\mathrm{H}_{4}$ & $\mathrm{H}_{5}$ \\
\hline Approved & $\checkmark$ & $\checkmark$ & & & $\checkmark$ \\
\hline Rejected & & & $\checkmark$ & $\checkmark$ & \\
\hline
\end{tabular}

\section{Conclusion}

This research has identified the influence of GC barriers on developing women's careers in the hospitality industry's private sector in Kosovo. After evaluating the research results, it became clear that some of the GC barriers influence the WCD. The findings proved that three hypotheses of the study are confirmed, and two rejected. Additionally, this research showed that GC has an influence of 56.7\% on WCD among female employees working in the hospitality industry's private sector.

Based on the analyzed data, it can be confirmed that there is a strong negative correlation between GC and WCD, with a correlation coefficient of -.672 at significance level of .000 . The regression analysis outcomes showed that three out of five variables are important variables for model construction, Internal Business Structural Barriers, Societal Barriers, and Personal Barriers. These variables have a pvalue less than .05 meaning that they influence the WCD, while Governmental Barriers, and Situational Barriers have a p-valuee greater than .05 and as such they do not contribute to model construction. From the analysis of the general findings of the study, it can be concluded that referring to the purpose of the study, the influence of "Glass ceiling" barriers on the WCD, the objectives of the study were achieved, and the influence of GC barriers on WCD was also identified, which enables the women career development in the private sector of the hospitality industry in Kosovo.

\section{References:}

Adler, N.J. 1993. Competitive Frontiers: Women Managers in the Triad. International Studies of Management and Organization, 23(2), 3-23.

Afza, S., Newaz, M. 2008. Factors determining the presence of GC and influencing women career advancement in bangladesh. Bbrac University Journal.

Bateson, M. 1994. Peripheral Visions: Learning Along the Way. New York: Harper Collins.

Bazazo, I., Nasseef, M.A., Mukattesh, B., Kastero, D., Al-Hallaq, M. 2017. Assessing the glass ceiling effect for women in tourism and hospitality. Journal of Management and Strategy, 8(3), 51.

Brownell, J., Walsh, K. 2008. Women in hospitality [Electronic version]. Retrieved [insert date], from Cornell University, SHA School site: http://scholarship.sha.cornell.edu/articles/835.

Cheryl De la Rey, “Gender, Women and Leadership," Agenda 65, (2005), 4-11.

Chimona, E., Mazirir, E. 2015. Women in Action: Challenges Facing Women Entrepreneurs. In the Gauteng Province of South Africa. International Business \& Economics Research Journal, 14(6), 835-845. 
Clevenger, L., Singh, N. 2013. Exploring Barriers That Lead to the Glass Ceiling Effect for Women in the U.S. Hospitality Industry. Journal of Human Resources in Hospitality \& Tourism, 12, 376-399.

Eagly, E., et al. 2003. Transformational, transactional, and laissez-fare leadership styles: A meta-analysis comparing women and men. Psychological Bulletin, 129, 569-591.

Elda, D., Oriola, Th. 2018. An empirical analysis of the barriers faced by Women managers in albanian banking sectorinternational. Journal of Economics, Commerce and Management United Kingdom, 6(2).

Freedman, D., Pisani, R., Purves, R. 2007. Statistics (international student edition). Pisani, R. Purves, 4th Edn. WW Norton Camp Company, New York.

Glass Ceiling Commission. 1995. Glass Ceiling Commission-Good for Business: Making Full Use of the Nation's Human Capital.

Kiaye, R., Singh, A. 2013. The Glass Ceiling: A Perspective of Women Working in Durban. Gender in Management: An International Journal, 28(1), 28-42.

Kosovo Agency of Statistics. 2020. (KAS, 2020), Social Statistics Labor Force Survey.

Marinakou, E. 2014. The Glass Ceiling and women in management in the Middle East: Myth or reality. Athens.

Myers, C. 2010. Perceptions of the Glass Ceiling Effect in Community Colleges. A Thesis Submitted in Partial Fulfillment of the requirement of University of New Orleans for the Doctor of Philosophy in Educational Administration.

Ng, C.W., Pine, R. 2003. Women and men in hotel management in Hong Kong: Perceptions of gender and career development issues. International Journal of Hospitality Management, 22(1), 85-102.

Oakley, J.G. 2000. Gender-based barriers to senior management positions: understanding the scarcity of female CEO's. Journal of Business Ethics, 27(4), 321-334.

Palikhe, A. 2018. Women Empowerment in Tourism: Special Reference to Pokhara Metropolitan City. The Journal of Nepalese Business Studies, 9(1).

Pallant, J. 2001. SPSS survival manual: A step by step guide to data analysis using SPSS for Windows version 10. Buckingham, Open University Press.

Pallant, J. 2005. SPSS Survival Guide: A Step by Step Guide to Data Analysis Using SPSS for Windows. 3rd Edition, Open University Press, New York.

Paustian-Underdahl, S.C., Walker, L.S.,Woehr, D.J. 2014. Gender and perceptions of leadership effectiveness: A meta-analysis of contextual moderators. Journal of Applied Psychology, 99(6), 1129-1145.

Riza I. Çavolli, Regional Geography of Kosovo, 319.

Satyal, Y.R. 2000. Tourism monograph of Nepal. Delhi, Abroit Publishers.

Schuh, S., Hernandez Bark, C., Van Quaquebeke, A., Hossiep, S., Frieg, N., Dick, R. 2014. Gender Differences in Leadership Role Occupancy: The Mediating Role of Power Motivation. Journal of Business Ethics, 120(3), 363-379.

Sekaran, U., Bougie, R. 2013 Research Methods for Business: A Skill-Building Approach. 6th Edition, Wiley, New York.

Steven, H.A., Shapiro, B.T., Didus, K., Luongo, T., Paz, B. 2013. Upward mobility for women managers: styles and perceptions: part two. Industrial and Commercial Training, 45(2), 110-118.

UNWTO. 2015. Why tourism? http://www2.unwto

Veale, C., Gold, J. 1998. Smashing into the glass ceiling for women managers. Journal of Management Development, 17(1), 17-26. 